\title{
Interferon Alpha/Beta Receptor 1
}

National Cancer Institute

\section{Source}

National Cancer Institute. Interferon Alpha/Beta Receptor 1. NCI Thesaurus. Code C37276.

Interferon alpha/beta receptor 1 (557 aa, $\sim 64 \mathrm{kDa}$ ) is encoded by the human IFNAR1 gene. This protein plays a role in interferon-dependent signal transduction. 